\title{
Effects of the fruiting period and growing seasons on market quality in goji berry (Lycium barbarum L.)
}

\author{
Mehmet Polat $^{1}$, Kerem Mertoglu ${ }^{2, *}$, Ilknur Eskimez $^{2}$, Volkan Okatan $^{3}$ \\ ${ }^{1}$ Department of Horticulture, Faculty of Agricultural Sciences and Technology, \\ Applied Sciences University of Isparta, Isparta, Turkey \\ ${ }^{2}$ Eskisehir Osmangazi Universitesi, Eskisehir, Turkey \\ ${ }^{3}$ Department of Horticulture, Faculty of Agriculture, Usak University, Usak, Turkey
}

\begin{abstract}
Progression of the vegetation period and change of year are associated with variations in general climatic parameters, such as temperature, atmospheric pressure, humidity, radiation, precipitation, wind speed and others. Only limited knowledge is available about the effects of these parameters on the characteristics of quality of fruits especially those with successive ripening such as goji berry. In our study, fruits of goji berry were characterised based on physico-chemical properties within four different harvest periods, in two consecutive years. Based on the obtained results, it was found that the pomological characteristics were superior at the beginning of the production season, while the phytochemical properties were better at the end. Fruit length, width and weight characteristics were noted to decrease from the first harvest to the last by $21 \%, 18 \%$ and $33 \%$, respectively, while the total anthocyanin, phenol and antioxidant activity properties increased by $264 \%, 48 \%$ and $105 \%$, respectively. There was a decrease in fruit weight, fruit length and fruit width up to $15.9 \%$, $18.3 \%$ and $6 \%$, respectively and were directly associated with yield due to sink competition among fruits. Providing high ripening index that ensures more acceptable fruits, with high soluble solid content (SSC) and titratable acidity (TA) seems to be a very important breeding objective to meet consumer demands thanks to superior organoleptic quality. According to correlations, the synthesis of phenolic compounds increased in parallel with SSC rise and TA, which improved pomological properties too. It is thought that the obtained results may indicate the cultural processes and evaluation methods to be used for the harvested fruits.
\end{abstract}

Keywords: harvesting time, fruit quality, Lycium barbarum L., phenolics, seasonal variation

\section{INTRODUCTION}

Consumption of berry fruits, which are defined as functional foods, has shown an increasing trend mainly because of their superior phytochemical properties (Demir and Aktas, 2018). These phyto-compounds have high antioxidant effects and reduce the risk of many chronic diseases, including cancer and cardiovascular diseases by preventing the onset of oxidation and peroxidation reactions (Tang and Tsao, 2017; Pham et al., 2019). Moreover, these compounds have been reported to improve the plant defence mechanisms against biotic and abiotic stress factors by regulating many different physiological processes (Verdaguer et al., 2017; Zheng et al., 2019).

Goji berry has also been described as 'food of health' and is a species belonging to the Solanaceae family in the Lycium genus (Levin and Miller, 2005). Apart from its dried and fresh consumption, its different uses in the industry have increased its importance and cultivation (Potterat, 2010). Ecological selectivity of goji berry is low and has the potential to be a complementary product

*Corresponding author. 
in agribusinesses especially in terms of evaluating the labour force of women and children (Levin and Miller, 2005).

The physico-chemical characteristics are mainly determined by the genotype, but ecological factors and cultural practices have also been reported to have a very decisive effect on these properties (Arena and Curvetto, 2008; Usanmaz et al., 2018). Meteorological parameters such as atmospheric layer thickness, the angle of the sun rays, light intensity, radiation, precipitation, temperature, pressure, humidity and wind speed vary significantly between the years. Based upon the changes in meteorological parameters, it has been reported that the yield, pomological and phytochemical characteristics have substantially undergone a change in many fruit species including goji berry (Galindo et al., 2015; Zorenc et al., 2016; Colak et al., 2019). Cool air during the fruit set period increases the yield and pomological properties by higher production of gibberellic acid and cytokinin in the calyx and growth cones (Ozga and Reinecke, 2003). However, this results in a decrease of biochemical properties in the unit area, which may be due to the increasing of the inter-cellular spaces (Ebel et al., 1993). Phytochemical accumulation is stimulated with the increase between day and night temperature difference due to increased photosynthesis (Sage and Kubien, 2007). Reduction in air and soil moisture reduces pomological characteristics, while phytochemical accumulation was triggered due to rising abscisic acid (Villalobos-Gonzalez et al., 2016).

Goji berry plants are known for their successive ripening, and berries are commercially harvested approximately every 10 days and the harvest period is spread over a period of 4-5 months (Colak et al., 2019). Serious differences are observed in the morphology and biochemistry of the harvested crops because of different climatic features existing in all harvest periods. Further, the physiological stage of plants varies during this fruiting period. This results in a significant influence on the marketability of the goji berry fruits, due to increased diversity in quality parameters. It is reported that the fruits harvested in the early period of the successive harvested fruit species are superior in terms of pomological properties; while the fruit flesh hardness and phytochemical characteristics are at lower levels (Zorenc et al., 2016). Moreover, these fruits are not suitable for storage due to their high pectinase enzyme activity and respiration rate (Erkan and Pekmezci, 2004; Ali et al., 2018; Ansari et al., 2018). Moreover, this situation will be opposite if the harvesting period is extended and continued.

Therefore, the main objectives of this work were to (1) determine how the quality parameters change in relation to the years and fruiting period of goji berry, (2) investigate the relations among the examined characteristics through correlation analysis for giving guidance to the cultural practices at farmer level and (3) conduct factor analysis to determine the variation sources and interrelations among the properties to provide comprehensive information for breeding studies.

\section{MATERIALS AND METHODS}

This study was carried out during two consecutive vegetation seasons in the years of 2017 and 2018 with 10 repetitions in Isparta, Turkey $\left(37^{\circ} 50^{\prime} 13.6464^{\prime \prime} \mathrm{N}\right.$, $\left.30^{\circ} 32^{\prime} 17.6316^{\prime \prime} \mathrm{E}\right)$. The seed of genotype belonging to Lycium barbarum was used as the plant material, which was planted in 2014 within and between rows of $1.2 \times 3.5$ $\mathrm{m}$ in an open field under natural conditions. Total area where cultivation is carried out is approximately $250 \mathrm{~m}^{2}$ and there are around 60 plants. The study was conducted by selecting the healthiest and homogenous ones. The climatic data of the experimental field was given in Table 1. Isparta is located in the transition zone between the Mediterranean and temperate climate. The air temperature has been decreased slightly in the

Table 1. Meteorological parameters of the experimental area in related years and months

\begin{tabular}{|c|c|c|c|c|c|c|c|c|c|}
\hline \multirow[b]{2}{*}{ Months - Years } & \multicolumn{3}{|c|}{ Precipitation (mm) } & \multicolumn{3}{|c|}{ Humidity (\%) } & \multicolumn{3}{|c|}{ Temperature $\left({ }^{\circ} \mathrm{C}\right)$} \\
\hline & 2017 & 2018 & 1990-2019 & 2017 & 2018 & 1990-2019 & 2017 & 2018 & $1990-2019$ \\
\hline January & 87.8 & 89.2 & 81.0 & 77.9 & 75.7 & 73.2 & -0.8 & 3.1 & 1.9 \\
\hline February & 3.6 & 30.8 & 67.6 & 68.5 & 75.7 & 70.2 & 3.0 & 6.3 & 2.9 \\
\hline March & 74.4 & 69.3 & 59.0 & 64.1 & 65.9 & 65.3 & 7.3 & 9.2 & 6.2 \\
\hline April & 25.6 & 6.3 & 52.4 & 59.6 & 51.0 & 61.0 & 10.6 & 14.2 & 10.8 \\
\hline May & 149.5 & 62.9 & 56.6 & 63.7 & 62.3 & 57.4 & 14.9 & 16.8 & 15.6 \\
\hline June & 30.9 & 69.4 & 34.2 & 58.9 & 62.4 & 51.2 & 20.1 & 20.0 & 20.2 \\
\hline July & 13.1 & 4.1 & 16.1 & 46.9 & 41.2 & 45.4 & 25.2 & 24.3 & 23.6 \\
\hline August & 20.4 & 14.2 & 14.1 & 52.1 & 47.6 & 46.4 & 24.3 & 23.8 & 23.2 \\
\hline September & 5.7 & 1.6 & 18.7 & 47.6 & 45.1 & 52.0 & 21.0 & 20.7 & 18.6 \\
\hline October & 46.5 & 30.6 & 38.3 & 61.8 & 63.4 & 62.1 & 13.0 & 13.8 & 13.0 \\
\hline November & 41.7 & 48.6 & 45.0 & 74.3 & 67.7 & 68.4 & 6.7 & 9.1 & 7.4 \\
\hline December & 31.2 & 107.1 & 87.2 & 76.6 & 82.7 & 74.5 & 5.0 & 3.5 & 3.5 \\
\hline
\end{tabular}


second year compared to the first year during the harvest period (between June and September). Precipitation and humidity were higher in June in 2018, while they were higher in the remaining months in 2017 during the harvest period. Irrigation was carried out with drip irrigation method in both years of the study because of insufficient amount of precipitation. All cultural management practices such as pruning, fertilisation, soil management, pest and disease control etc. were regularly conducted in both years.

In both years of the study, the harvests were carried out between June and September. Fruits were harvested three times in a month, at intervals of 10 days. All mature fruits were harvested in each harvest from the plants at consumption maturity according to the sense of taste, colour and abscission layer, and they were harvested by a single person to maintain consistency of maturity degree (Eskimez et al., 2019). As each plant is a separate one and undergoes repetition, fruits of each plant were harvested without mixing with the fruit from other plants and divided into two parallel with each parallel consisting of randomly selected 20 fruits for each harvest. One of the parallels was used for the measurement of the pomological characteristics (20 fruits for each repetition in each harvest) and the other for phytochemical properties.

Harvested fruits were immediately transferred to the laboratory. Fruit width and length were measured with a digital calliper (Stilson). An electronic scale with 0.001 g-accuracy (Sartorius - CPA 16001S) was used for the determination of fruit weight (Karacal1, 2012). Plant yield was determined by taking the arithmetic mean of yields that were obtained from each repetition during the fruiting period (Eskimez et al., 2019). Soluble solid content and $\mathrm{pH}$ values were measured from the juices (obtained from approximately 13-14 fruits for each repetition in each harvest). Juice extractor was used to obtain fruits' juices, and then filtered through Whatman paper. Finally, they were centrifuged and the upper portions of the solutions were used directly. Digital refractometer (Atago PR-32) was used to determine the total soluble solids content (SSC) and the results were expressed as \% (Karacal1, 2012). Titratable acidity (TA), was estimated from the water extract content of the juices $(5 \mathrm{~mL}$ juice and $20 \mathrm{~mL}$ water) by titrating with $0.1 \mathrm{~N} \mathrm{NaOH}(\mathrm{pH}$ 8.1) until the colour is changed under the phenolphthalein indicator. Results were calculated using the formulation proposed by Karacalı (2012) and expressed in percentage equivalence of malic acid\%. Ripening index was obtained by proportioning the SSC to TA (Eskimez et al., 2019; Szot et al., 2019).

The spectrophotometrical analyses were conducted when the last harvest was done in each year. Seeds of previously harvested fruits were separated from the flesh and sliced with a sharp knife and stored at $-20^{\circ} \mathrm{C}$. To prepare the fruit extracts, $5 \mathrm{~g}$ of fresh fruit samples (obtained from approximately 6-7 fruits for each repetition in each harvest) from each parallel was extracted with $10 \mathrm{~mL}$ of $80 \%$ acetone containing $0.2 \%$ formic acid, using a homogeniser for $2 \mathrm{~min}$. Then centrifuged at $20,000 \times \mathrm{g}$ for $20 \mathrm{~min}$ at $4^{\circ} \mathrm{C}$ (Selcuk and Erkan, 2016).

Folin-Ciocalteu method was used for the determination of total phenolic content as defined by Mertoglu et al. (2020). The fruit juice was mixed with Folin-Ciocalteu reagent and distilled water at a ratio of 1:1:18 and left to rest for $8 \mathrm{~min}$, then $7 \%$ sodium carbonate was added. After $2 \mathrm{~h}$ of incubation in a dark room, the absorbance of the bluish solution was measured at $750 \mathrm{~nm}$. Gallic acid was used as an external standard for the calibration curve and the results were represented as gallic acid equivalents of fruit juice (mg GAE $\cdot \mathrm{L}^{-1}$ fresh weight).

Total monomeric anthocyanin content was determined by the $\mathrm{pH}$ differential method based on the property of anthocyanin pigments to change the colour with $\mathrm{pH}$ (Giusti and Wrolstad, 2001). Two dilutions of the same sample were prepared, the first one in potassium chloride buffer $(0.025 \mathrm{M}, \mathrm{pH} 1.0)$ and the second one in sodium acetate buffer (0.4 M, pH 4.5), $\mathrm{pH}$ was adjusted with $0.2 \mathrm{~N} \mathrm{HCl}$ and the absorbance measured at both $520 \mathrm{~nm}$ and $700 \mathrm{~nm}$, respectively. Formula (1) was used for the calculations and results were given as $\mathrm{mg}$ cyanidin-3-glucoside $\cdot \mathrm{L}^{-1}$ fresh: where $\mathrm{A}=[(\mathrm{A} 520-$ A700) $\mathrm{pH} 1.0$ - (A520 - A700) pH 4.5], MW (molecular weight $)=449.2 \mathrm{~g} \cdot \mathrm{mol}^{-1}$ for cyanidin-3-glucoside, $\mathrm{DF}=$ dilution factor, $\mathcal{E}=26,900$ molar extinction coefficient, in $\mathrm{L} \cdot \mathrm{mol}^{-1} \cdot \mathrm{cm}^{-1}$, for cyanidin-3-glucoside.

Total monomeric anthocyanin $\left(\mathrm{mg} \cdot \mathrm{kg}^{-1}\right)$

$=(\mathrm{A} \times \mathrm{MW} \times \mathrm{DF} \times 1,000) \cdot \varepsilon^{-1}$.

Antioxidant activity analyses were performed using DPPH (2.2-diphenyl-1-picrylhydrazyl) method according to Selcuk and Erkan (2014) by determining the scavenging rate of the methanolic extracts in the samples of the DPPH radical. Briefly, $100 \mu \mathrm{L}$ of methanolic extract diluted at a $1 / 10$ ratio was mixed with $3.9 \mathrm{~mL}$ of $6 \times 10^{5} \mathrm{M}$ DPPH solution and left to rest for $30 \mathrm{~min}$ in a dark, and then the results were measured using a double-beam UV-Vis spectrophotometer at $515 \mathrm{~nm}$ and results were expressed for $\mathrm{IC}_{50}$ values as $\mu \mathrm{L} \cdot \mathrm{mL}^{-1}$ fresh weight.

The spectrophotometrical method was used to determine the amount of vitamin $\mathrm{C}$ (L-ascorbic acid). Further, 2,6-dichlorophenolindophenol (2,6-D) was utilised to reduce the colouring material. Accordingly, a standard curve was obtained with the solutions prepared using oxalic acid, ascorbic acid and 2,6-D as a colouring material. First, $10 \mathrm{~mL}$ of fruit juice was extracted and diluted with oxalic acid 10 times; then it was drawn into 2 tubes, $1 \mathrm{ml}$ for each, where one was mixed with $9 \mathrm{~mL}$ of distilled water while the other was mixed with $9 \mathrm{~mL}$ of the 2,6-D colouring material. The obtained solutions were analysed by a spectrophotometer at $518 \mathrm{~nm}$. Absorbance values were substituted in the standard curve and the corresponding ascorbic acid amounts 
were found and given as $\mathrm{mg} \cdot 100 \mathrm{~mL}^{-1}$ fresh weight (Okatan and Colak, 2019).

The study was designed in accordance with the randomised plot factorial experimental design. The statistical model of the study years and harvest periods (three harvests in each month were merged for the analysis) were regarded as independent factors. Minitab-17 statistical package program was used in the statistical analyses. Homogeneity of variance was checked for all investigated characteristics before the application of ANOVA. Differences between the levels and interactions of the factors were found using the Tukey (HSD) multiple comparison tests. Linear correlation analysis was used to determine the relationship between the characteristics and expressed with Pearson correlation coefficients. Principal component analysis (PCA) was used to examine the interrelations among the observed set of variables to identify the similarities and differences of characteristics. Further, a scatter plot based on the first two principal components (PC1 and PC2) was generated. The first component describes most of the variation in the data. The second principal component is orthogonal and covers most of the remaining variation (Zar, 2013).

\section{RESULTS AND DISCUSSION}

All the investigated characteristics of goji berry varied at a statistical level among the years and harvest periods. The effect of year was found to be more important on the variation in fruit length, titratable acidity (TA), ripening index, $\mathrm{pH}$, vitamin $\mathrm{C}$, total phenol and antioxidant activity characteristics, while harvest period contributed more to the total variation in fruit width, fruit weight, yield, soluble solid content (SSC) and total monometric anthocyanin properties (F-values of the factors were added to the ANOVA table). In addition, the interaction of factors on some characteristics was found to be important (Table 2).

While the highest values in terms of fruit length, fruit width, and fruit weight were obtained at the beginning of the harvest season, a continuous decrease was observed in the further days of the harvest season. In June, the fruit length, fruit width, and fruit weight characteristics, which were measured as $18.03 \mathrm{~mm}, 10.32 \mathrm{~mm}$ and $1.02 \mathrm{~g}$, respectively, decreased to $14.18 \mathrm{~mm}, 8.47 \mathrm{~mm}$ and $0.68 \mathrm{~g}$ in September (Table 2). Because the crop load is low at the beginning of the harvest season, the fruit sizes and weight are relatively high since the assimilation products are carried to less fruit as reported in having successive ripening berry species including goji berry (Zorenc et al., 2016; Colak et al., 2019). All of the investigated pomological properties also differed significantly over the years. The yield per plant was $598.00 \mathrm{~g}$ in 2017 where lower values were obtained in terms of pomological properties. Larger and heavier fruits were harvested in 2018 because of the decrease in yield $\left(402.25 \mathrm{~g} \cdot\right.$ plant $\left.^{-1}\right)$. Linear relationships were determined between yield and pomological characteristics using the two-year data.
Based upon the obtained results, it was noted that the decrease in fruit weight, fruit length and fruit width up to $15.9 \%, 18.3 \%$ and $6 \%$, respectively were directly associated with yield (Figure 1). Increased crop load was found to cause a decrease in physical properties due to sink competition among fruits and these results were in agreement with Galindo et al. (2015) and Mertoglu et al. (2019a). The effect of ecological factors on these properties is also important. During the flowering and fruit set stages, cool weather allowed increased gibberellic acid and cytokinin production in growth cones (Ozga and Reinecke, 2003). This increased the fruit sizes and weight by increasing the number of cells. In the second year of study, the air temperature remained at lower levels during the whole fruiting period (Table 1). These factors affect the difference in pomological properties between years.

Soluble solid content $18.30 \%$ measured was the lowest amount in the first fruiting month (June) while it increased steadily in the remaining period and reached the maximum value at the final month (September) to $20.88 \%$. At the beginning of the harvest season, the fruit growth will be faster due to the lower crop load. However, this fast course in development physiology lead to more inter-cellular space and causing a decrease in the components that make up the dry matter in the unit volume (Mertoglu et al., 2019b). For example, the total amount of phenol and anthocyanins were consistently increased during the harvest season both in 2017 and 2018 (Figures 2A and 2B). Based upon the results of the two-year data, the amounts of these properties were found to be $31 \%$ and $107 \%$ higher in the last harvest compared to the first, respectively (Table 2). Similar results also have been reported by Zorenc et al. (2016) and Colak et al. (2019). Since plant development continues actively at the beginning of the harvest season, carbon sources are used for a higher rate of plant development. However, after that when plant growth is balanced, an increase is observed in the amount of these compounds since carbon sources are used more for secondary compound production (Arena and Curvetto, 2008). Also, it is noted that the increase in air temperature and the decrease in water use efficiency during the vegetation period contributed to this situation. Further, plants produce phenolic compounds with high UV absorbing ability in epidermal tissues, in the phenylpropanoid pathway (Verdaguer et al., 2017) as a defence mechanism against the harmful effects of high UV rays that are increased with temperature. In water stress, ABA production, which triggers ripening is increases and ABA especially promotes sugar and anthocyanin production. In grapes, externally applied ABA increased the amount of anthocyanins in the berries by stimulating the genes (VvANS, VvMybA1 and $\mathrm{VvMyb4a)}$ responsible for the production of anthocyanins (Villalobos-Gonzalez et al., 2016)., Total phenol and anthocyanin levels increase towards the end of the production season, including berries in many fruit species (Zorenc et al., 2016). 
Table 2. Yield and psycho-chemical characteristics of the goji berry according to the factors

\begin{tabular}{|c|c|c|c|c|}
\hline & Fruit length (mm) & Fruit width (mm) & Berry weight (g) & Yield $\left(\mathrm{g} \cdot\right.$ plant $\left.^{-1}\right)$ \\
\hline \multicolumn{5}{|l|}{ Year (Y) } \\
\hline 2017 & $15.34 \mathrm{~B}$ & $9.21 \mathrm{~A}$ & $0.80 \mathrm{~B}$ & $598.00 \mathrm{~A}$ \\
\hline 2018 & $17.09 \mathrm{~A}$ & $9.86 \mathrm{~B}$ & $0.92 \mathrm{~A}$ & $402.25 \mathrm{~B}$ \\
\hline \multicolumn{5}{|c|}{ Harvest period (Hp) } \\
\hline June & $18.03 \mathrm{~A}$ & $10.32 \mathrm{~A}$ & $1.02 \mathrm{~A}$ & $50.88 \mathrm{D}$ \\
\hline July & $16.50 \mathrm{~B}$ & $9.73 \mathrm{~B}$ & $0.88 \mathrm{~B}$ & $155.63 \mathrm{~B}$ \\
\hline August & $16.16 \mathrm{~B}$ & $9.63 \mathrm{~B}$ & $0.85 \mathrm{~B}$ & $192.63 \mathrm{~A}$ \\
\hline September & $14.18 \mathrm{C}$ & $8.47 \mathrm{C}$ & $0.68 \mathrm{C}$ & $101.00 \mathrm{C}$ \\
\hline \multicolumn{5}{|c|}{ ANOVA (with $F$-values) } \\
\hline $\mathrm{Y}$ & $* * *(157.48)$ & $* * *(62.78)$ & $* * *(49.29)$ & $* * *(303.26)$ \\
\hline $\mathrm{Hp}$ & $* * *(129.45)$ & $* * *(89.04)$ & $* * *(69.54)$ & $* * *(488.85)$ \\
\hline \multirow[t]{2}{*}{$\mathrm{Y}^{*} \mathrm{Hp}$} & ns & $* *(5.05)$ & ns & $* * *(11.28)$ \\
\hline & SSC (\%) & $\mathrm{pH}$ & TA (\%) & Ripening index \\
\hline \multicolumn{5}{|l|}{ Year (Y) } \\
\hline 2017 & $20.32 \mathrm{~A}$ & $4.86 \mathrm{~A}$ & $0.48 \mathrm{~B}$ & $41.65 \mathrm{~A}$ \\
\hline 2018 & $19.52 \mathrm{~B}$ & $4.50 \mathrm{~B}$ & $0.60 \mathrm{~A}$ & $34.52 \mathrm{~B}$ \\
\hline \multicolumn{5}{|c|}{ Harvest period (Hp) } \\
\hline June & $18.30 \mathrm{C}$ & $4.34 \mathrm{C}$ & $0.62 \mathrm{~A}$ & $29.89 \mathrm{C}$ \\
\hline July & $20.01 \mathrm{~B}$ & $4.76 \mathrm{~B}$ & $0.54 \mathrm{~B}$ & $37.82 \mathrm{~B}$ \\
\hline August & $20.48 \mathrm{AB}$ & $4.76 \mathrm{~B}$ & $0.52 \mathrm{~B}$ & $39.70 \mathrm{~B}$ \\
\hline September & $20.88 \mathrm{~A}$ & $4.85 \mathrm{~A}$ & $0.47 \mathrm{C}$ & $44.92 \mathrm{~A}$ \\
\hline \multicolumn{5}{|l|}{ ANOVA } \\
\hline $\mathrm{Y}$ & $* *(14.39)$ & $* * *(364.26)$ & $* * *(77.20)$ & $* * *(80.20)$ \\
\hline $\mathrm{Hp}$ & $* * *(28.86)$ & $* * *(147.28)$ & $* * *(19.66)$ & $* * *(61.17)$ \\
\hline \multirow[t]{2}{*}{$\mathrm{Y}^{*} \mathrm{Hp}$} & $* *(8.06)$ & $* * *(11.82)$ & ns & ns \\
\hline & $\begin{array}{c}\text { Vitamin C } \\
\left(\mathrm{mg} \cdot 100 \mathrm{~mL}^{-1} \text { fresh }\right. \\
\text { weight }) \\
\end{array}$ & $\begin{array}{c}\text { Total phenol } \\
\left(\mathrm{mg} \cdot \mathrm{GAE}^{-1} \cdot \mathrm{L}^{-1}\right. \\
\text { fresh weight })\end{array}$ & $\begin{array}{c}\text { TMA (mg cyanidin-3- } \\
\text { glucoside } \cdot \mathrm{L}^{-1} \text { fresh } \\
\text { weight) }\end{array}$ & $\begin{array}{c}\text { Antioxidant activity } \\
\left(\mu \mathrm{L} \cdot \mathrm{mL}^{-1} \text { fresh }\right. \\
\text { weight })\end{array}$ \\
\hline \multicolumn{5}{|l|}{ Year $(\mathrm{Y})$} \\
\hline 2017 & $38.49 \mathrm{~B}$ & $296.54 \mathrm{~B}$ & $20.53 \mathrm{~B}$ & $162.18 \mathrm{~B}$ \\
\hline 2018 & $58.32 \mathrm{~A}$ & $382.19 \mathrm{~A}$ & $30.28 \mathrm{~A}$ & $233.91 \mathrm{~A}$ \\
\hline \multicolumn{5}{|c|}{ Harvest period (Hp) } \\
\hline June & $57.94 \mathrm{~A}$ & $262.91 \mathrm{D}$ & $11.69 \mathrm{D}$ & $123.82 \mathrm{D}$ \\
\hline July & $53.68 \mathrm{~A}$ & $341.92 \mathrm{C}$ & $17.87 \mathrm{C}$ & $190.84 \mathrm{C}$ \\
\hline August & $46.35 \mathrm{~B}$ & $363.75 \mathrm{~B}$ & $29.51 \mathrm{~B}$ & $224.01 \mathrm{~B}$ \\
\hline September & $35.67 \mathrm{C}$ & $388.89 \mathrm{~A}$ & $42.54 \mathrm{~A}$ & $253.51 \mathrm{~A}$ \\
\hline \multicolumn{5}{|l|}{ ANOVA } \\
\hline $\mathrm{Y}$ & $* * *(186.37)$ & $* * *(360.91)$ & *** (156.83) & $* * *(445.33)$ \\
\hline $\mathrm{Hp}$ & $* * *(45.05)$ & $* * *(145.92)$ & $* * *(305.21)$ & $* * *(268.60)$ \\
\hline $\mathrm{Y}^{*} \mathrm{Hp}$ & $* * *(9.37)$ & $*(4.08)$ & $* * *(18.33)$ & $* * *(26.78)$ \\
\hline
\end{tabular}

Total phenol and anthocyanin amounts were determined at higher levels in all harvest periods of 2018 and compared to those in 2017 (Figures 2A and 2B) with statistical significance between years (Table 2). Parallel to climatic differences, serious changes are observed in phytochemical characteristics and especially during the period close to the harvest time, the factors light intensity and quality, humidity, differences between diurnal and nocturnal temperatures are highly decisive on the amount and final composition of biochemical 

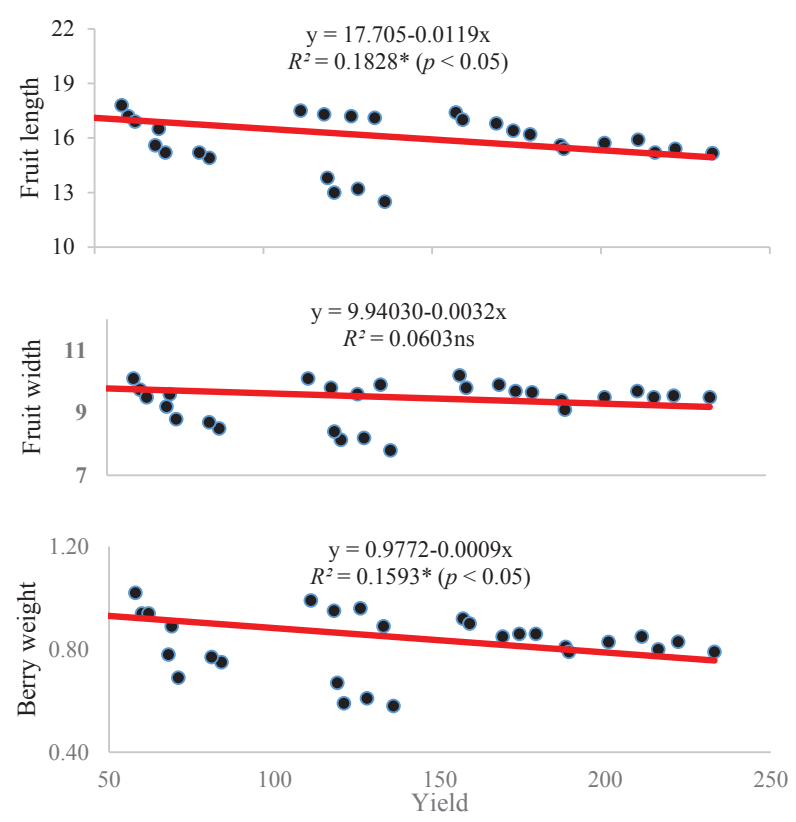

Figure 1. Regressions of yield with physical characteristics (* significant at $p \leq 0.05$, ns: non-significant).
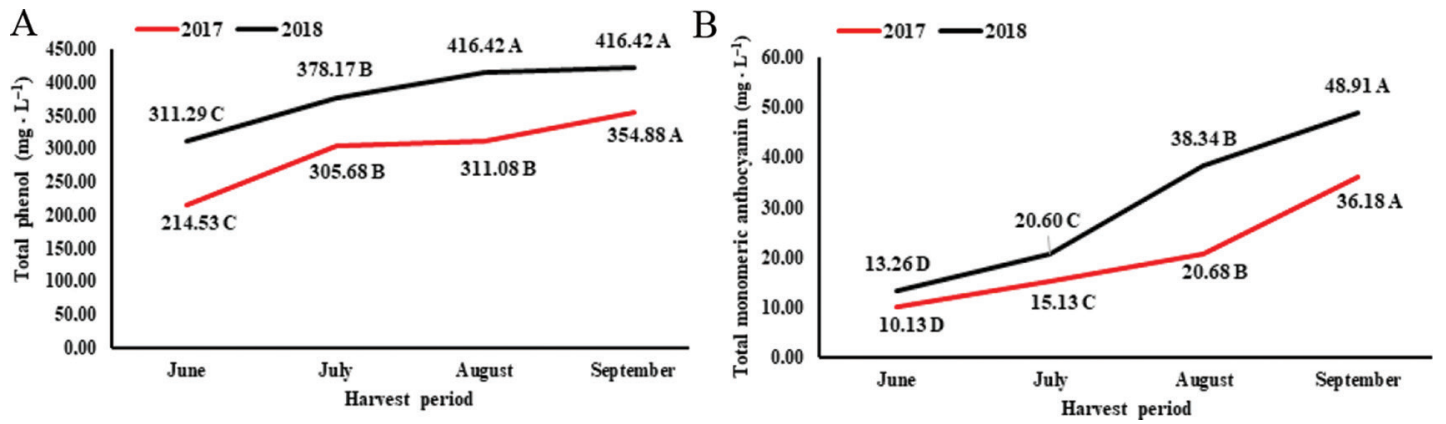

Figure 2. Change of total phenol and monometric anthocyanin content according to years and harvest periods.

compounds (Mphahlele et al., 2014; Usanmaz et al., 2018). The increase in the amount of phenol and anthocyanin properties positively affected the antioxidant activity by resulting in an increased activity. The antioxidant activity, which was measured as 123.82 at the beginning of the harvest period, increased continuously and reached 253.51 at the end of the harvest period (Table 2). It has been reported by Dai and Mumper (2010) that phenolic compounds have high antioxidant properties.

It has been determined that titratable acidity and $\mathrm{pH}$ properties were inversely proportional. Highest titratable acidity value was measured in June (0.62\%), while steady decrease was observed in the subsequent months and it was the lowest in September (0.47\%). On the contrary, $\mathrm{pH}$ was increased from 4.34 to 4.85 with increase by $11.7 \%$ between first (June) and last (September) harvest. The observed variation in any of these properties was seen as $74 \%$, due to the changes in other (Figure 3A). Preparations for winter begin at the end of the production season for deciduous fruit species. The activity of the hydrolase enzyme that catabolizes organic acids increases in this phase. Organic acids with very low respiratory coefficients are converted into sugar, which is used as a high energy source at this phase. Therefore, the titratable acidity is decreased. Additionally, intensive assimilate transfer is carried out to the fruits on the plant during this period to ripen the seed with the instinct to continue its generation. The maturity index increases because of these cumulative factors existing in these situations which allow the fruits to become sweeter. In the study, the maturity index increased by $43 \%$ in 2017 and $59 \%$ in 2018 in the last harvest compared to the first harvest (Figure 2B).

Correlation coefficients between the investigated characteristics are given in Table 3. A high level of positive correlation was detected between fruit width and fruit length $\left(0.96^{* * *}\right)$. After fertilisation, the cell number of the plants is increased and subsequently cell expansion occurs. In dicotyledon plants, assimilates are produced as a result of the transmission of metabolic events to growth cones indiscriminately. So, both horizontal and vertical growth progress are in parallel. Volume increase in cells that make up the fruit increases the weight too. In this context, a strong positive relationship was detected between fruit weight 

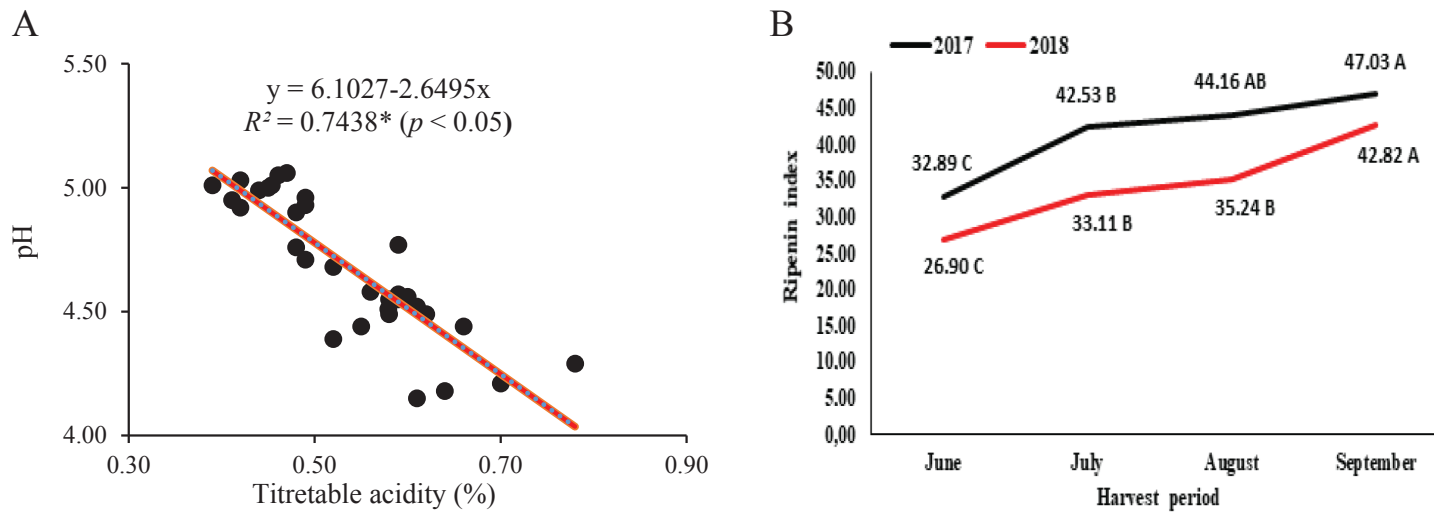

Figure 3. Regression between titratable acidity and $\mathrm{pH}(\mathrm{A})$, ripening index values according to years and harvest periods (B).

Table 3. Correlation coefficients among the investigated characteristics

\begin{tabular}{|c|c|c|c|c|c|c|c|c|c|c|c|}
\hline & FL & FW & $\mathrm{BW}$ & Yield & $\mathrm{SSC}$ & $\mathrm{pH}$ & TA & RI & Vit C & ТPC & TMA \\
\hline FW & $0.96^{* * *}$ & & & & & & & & & & \\
\hline BW & $0.97 * * *$ & $0.94 * * *$ & & & & & & & & & \\
\hline Yield & $-0.43^{*}$ & $-0.25 \mathrm{~ns}$ & $-0.40^{*}$ & & & & & & & & \\
\hline $\mathrm{SSC}$ & $-0.37^{*}$ & $-0.40^{*}$ & $-0.46^{* *}$ & $0.30 \mathrm{~ns}$ & & & & & & & \\
\hline $\mathrm{pH}$ & $-0.83^{* * *}$ & $-0.72 * * *$ & $-0.79 * * *$ & $0.72 * * *$ & $0.39 *$ & & & & & & \\
\hline TA & $0.86^{* * *}$ & $0.78^{* * *}$ & $0.80^{* * *}$ & $-0.54^{* *}$ & $-0.19 \mathrm{~ns}$ & $-0.86^{* * *}$ & & & & & \\
\hline RI & $-0.89^{* * *}$ & $-0.82 * * *$ & $-0.87 * * *$ & $0.56^{* *}$ & $0.46^{* *}$ & $0.91 * * *$ & $-0.94 * * *$ & & & & \\
\hline Vit C & $0.85^{* * *}$ & $0.80^{* * *}$ & $0.81^{* * *}$ & $-0.41^{*}$ & $-0.23 \mathrm{~ns}$ & $-0.81^{* * *}$ & $0.88 * * *$ & $-0.85^{* * *}$ & & & \\
\hline TPC & $-0.20 \mathrm{~ns}$ & $-0.24 \mathrm{~ns}$ & $-0.30 \mathrm{~ns}$ & $0.13 \mathrm{~ns}$ & $0.74 * * *$ & $0.08 \mathrm{~ns}$ & $0.06 \mathrm{~ns}$ & $0.19 \mathrm{~ns}$ & $0.09 \mathrm{~ns}$ & & \\
\hline TMA & $-0.51^{* *}$ & $-0.57 * *$ & $-0.60 * * *$ & $0.04 \mathrm{~ns}$ & $0.76^{* * *}$ & $0.26 \mathrm{~ns}$ & $-0.23 \mathrm{~ns}$ & $0.45^{* *}$ & $-0.30 \mathrm{~ns}$ & $0.83^{* * *}$ & \\
\hline $\mathrm{AOA}$ & $-0.30 \mathrm{~ns}$ & $-0.36^{*}$ & $-0.42 *$ & $0.13 \mathrm{~ns}$ & $0.80^{* * *}$ & $0.15 \mathrm{~ns}$ & $-0.04 \mathrm{~ns}$ & $0.28 \mathrm{~ns}$ & $-0.05 \mathrm{~ns}$ & $0.95 * * *$ & $0.92 * * *$ \\
\hline
\end{tabular}

AOA, Antioxidant activity; BW, Berry weight; FL, Fruit length; FW, Fruit width; ns, non-significant; RI, Ripening index; SSC, soluble solid content; TA, Titratable acidity; TMA, Total monometric anthocyanin; TPC, Total phenol content; Vit C, Vitamin C.

*, **, ***: correlations are significant at $p<0.05, p<0.01$ and $p<0.001$, respectively.

and fruit width and fruit length, respectively, at $0.94 * * *$ and $0.97 * * *$ (Table 3). A strong and positive relationship between fruit physical characteristics also has been reported in different species (Lo Bianco et al., 2010; Saridas et al., 2017). On the other hand, all of these properties were found in a negative correlation with yield. But the statistical significance was determined between yield and fruit size $\left(-0.43^{*}\right)$ and fruit weight $\left(-0.40^{*}\right)$ (Table 3$)$. Increase in fruit set was negatively affected fruit sizes and weight due to carbohydrate competition among fruits (Reig et al., 2016; Mertoglu et al., 2019a).

Inter-cellular spaces among the cells are increased in parallel to the increase in volume. Generally, this causes a decrease in the amount of compounds that constitute dry matter. According to the result of this study, fruit sizes and weight characteristics associated with the fruit volume increase were determined to be weak or strong but had a negative correlation with the total phenol, anthocyanin and antioxidant activity properties (Table 3). Similarly, Radunic et al. (2015) have reported that the increase in physical properties decreases the biochemical content.
Ascorbic acid (vitamin C) has an acidic character and increases as the acidity of the environment (Mertoglu and Evrenosoglu, 2019). Therefore, strong positive relationship between vitamin $\mathrm{C}$ and titratable acidity was found with $r=0.88^{* * *}$ correlation coefficient (Table 3) in agreement with I Forcada et al. (2014). The value of $\mathrm{pH}$ increases due to the breakdown of organic acids that carrying $\mathrm{H}^{+}$ion. A high and negative correlation between $\mathrm{pH}$ and titratable acidity determined in the present study is related to this $\left(r=-0.86^{* * *}\right)$. In this context, vitamin $\mathrm{C}$, which has a positive correlation with titratable acidity, was detected to have a high negative correlation with $\mathrm{pH}\left(r=-0.81^{* * *}\right)$. Obtained results were found compatible with the literature (Vieira et al., 2009; Mertoglu and Evrenosoglu, 2019).

The correlation coefficients between antioxidant activity with total phenol and anthocyanin properties were found to be $r=0.95^{* *}$ and $r=0.92 * * *$, respectively. High level of positive correlation between these properties, confirms the antioxidative effects of these compounds. Dai and Mumper (2010) have similarly reported that the phenolic compounds have high antioxidant activity. A positive correlation between 
total phenol and anthocyanin with antioxidant activity has been reported in many other fruit species too ( $\mathrm{He}$ et al., 2015; Chang et al., 2019). On the other hand, an insignificant negative correlation was detected between vitamin $\mathrm{C}$ and antioxidant activity, as reported by Okatan (2020), probably due to antioxidants except ascorbic acid may mostly contribute to the total antioxidant activity (Reig et al., 2016). Thus, the lower content of vitamin C than other antioxidant compounds may have caused this situation. A positive relationship between vitamin $\mathrm{C}$ and antioxidant activity in some other species such as apple and pear was noted to have lower phenolic compounds (Vieira et al., 2009; Mertoglu and Evrenosoglu, 2019). These situations suggest that breeders prioritise phenolic compounds for the development of antioxidant activityrich cultivars.

As expected, ripening index (RI) was found to have a positive correlation with $\operatorname{SSC}\left(0.46^{* *}\right)$, while negative relation was detected with TA $\left(-0.94^{* * *}\right)$, since RI is the ratio of SSC to TA as reported previously by Eskimez et al. (2019) (Table 3). Usually, a higher ratio means more acceptable fruit in terms of flavour with a sweet taste (Crisosto and Crisosto, 2005). An adequate amount of individual sugars that contribute to SSC is extremely important for the synthesis of phenolic compounds, which is responsible for blush (Tomas-Barberan and Espin, 2001). Colour is known as an important criterion for consumer perception as it increases fruit appeal and sales (Liverani et al., 2002). In transgenic tomato plants, acidity has been found to be very significant in improving the pomological properties of the fruits via increasing cell expansion (Centeno et al., 2011). In the study, the high positive correlation of TA with fruit length $\left(0.86^{* * *}\right)$, fruit width $\left(0.78^{* * *}\right)$ and berry weight $\left(0.80^{* * *}\right)$ is parallel to this situation. In the light

Table 4. Eigenvalues and total variability proportion of first three principal component (PC) axes for investigated characteristics components

\begin{tabular}{lrrr}
\hline & PC1 & PC2 & PC3 \\
\hline Fruit length & 0.948 & -0.173 & -0.181 \\
Fruit width & 0.906 & -0.072 & -0.346 \\
Berry weight & 0.951 & -0.046 & -0.186 \\
Yield & -0.536 & 0.206 & -0.778 \\
SSC & -0.585 & -0.646 & -0.226 \\
pH & -0.874 & 0.321 & -0.271 \\
TA & 0.852 & -0.450 & 0.011 \\
Ripening index & -0.945 & 0.202 & -0.059 \\
Vitamin C & 0.832 & -0.411 & -0.146 \\
Total phenol & -0.379 & -0.883 & -0.120 \\
Total anthocyanin & -0.641 & -0.709 & 0.207 \\
Antioxidant activity & -0.484 & -0.858 & -0.040 \\
Expl. Var & 7.116 & 3.032 & 1.020 \\
Prp. Total & 0.593 & 0.253 & 0.085 \\
Cumulative \% & 59.302 & 84.566 & 0.931 \\
\hline
\end{tabular}

of all these findings, it can be said that providing high ripening index with high SSC and TA is a very important breeding objective to meet consumer demands thanks to superior organoleptic quality (Crisosto and Crisosto, 2005).

Furthermore, to obtain a broad view of the relations between physicochemical characteristics, the whole data set was subjected to principal component analysis (PCA). The same method was adopted in lots of berry species such as mulberry (Garcia-Gomez et al., 2019), grape (Abiri et al., 2020), saskatoon (Lachowicz et al., 2020) and including goji berry (Donno et al., 2015) for the determination of variation sources, correlations among the properties, or genetic diversity of genotypes.

PCA results indicated that the first three components explain about $93.1 \%$ of the total observed variability (Table 4). PC1 consists of fruit length, fruit width, berry weight, $\mathrm{pH}, \mathrm{TA}$ and ripening index characteristics and explained $59.30 \%$ of the total variation in the data set while PC2 explained $25.26 \%$ with SSC, total phenol, total monometric anthocyanin and antioxidant activity (Table 4). This can be interpreted as the fact that variation caused by year and harvest period occurs largely in physical properties, whereas variations in chemical properties occur later. Similar findings were reported in different fruit species (Rakonjac et al., 2010; Hashemi and Khadivi, 2020).

Scatter plot for PC1 and PC2 $(84.56 \%$ of total variance) for the investigated characteristics of goji berry (Lycium barbarum L.) is seen in Figure 4. Examined characteristics were gathered under three groups. The properties of titratable acidity, vitamin $\mathrm{C}$, fruit width, fruit length and fruit weight that constitute the first group have a positive relationship with each other, but they were in negative relation with the maturity index. $\mathrm{pH}$ and yield characteristics that constitute the second group due to the diagonal position of them on the chart. The third group comprises of total phenol, total monometric anthocyanin, antioxidant activity and soluble solid content. Characteristics of the third group have high positive relations among themselves,

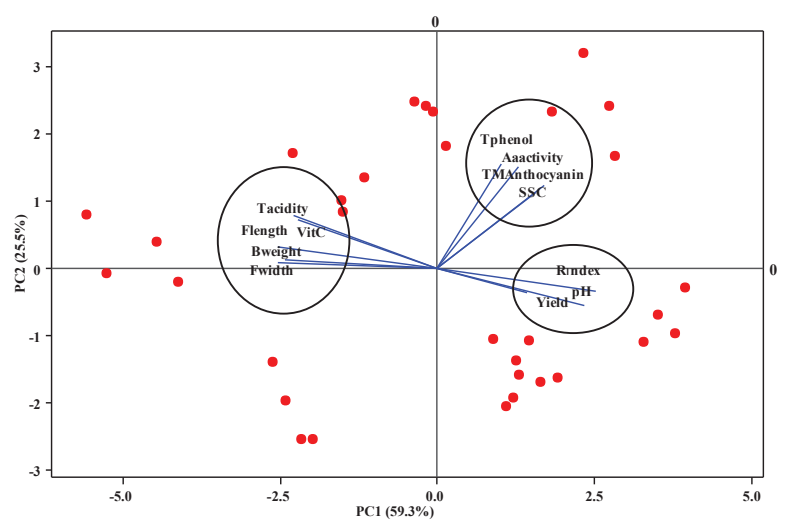

Figure 4. Biplot with first two principal components for quality attributes in goji berry (red dots represent merged repetitions). 
have low and positive relations with the members of the second group which are located in the positive part of the platform, but have negative relations with members of the first group due to their location in the negative side of PC1. It can be seen that the obtained results are compatible with the correlation coefficients given in Table 3. Associations between traits emphasised by this method may correspond to genetic the linkage between loci controlling traits or a pleiotropic effect (Iezzoni and Pritts, 1991).

\section{CONCLUSION}

Result of present study showed that the effects of years and harvest periods on physico-chemical properties were significant. Pomological characteristics were found to be superior at the beginning of the production season, while the phytochemical properties were better at the end of the harvest season. This means that the early harvested fruits are more suitable for fresh consumption whereas harvested fruits at later periods are more appropriate for industrial processing. Results also suggested that the crop load must be taken into consideration due to its direct effects on organoleptic properties for better goji berry cultivation. The high sensitivity of the fruit characteristics to the ecological factors also made it possible to suggest that the cultural practices should be performed carefully for goji berry production. It is thought that weak shading during fruit set periods and low drought stress close to ripening phase would increase fruit quality. Positive effects of acidity on physical properties and SSC triggering of phenolic compound synthesis by soluble solid content suggest that breeders should prioritise by providing high ripening index with high SSC and TA, which is a very important objective to meet consumer demands.

\section{FUNDING}

None.

\section{AUTHOR CONTRIBUTIONS}

K.M. and M.P. designed the research. All of the authors contributed equally to the field and laboratory studies in addition to spectrophotometric analysis. K.M. made statistical analyses, interpretation of the results and writing the original draft. All authors read and approved the final draft of the manuscript.

\section{CONFLICT OF INTEREST}

Authors declare no conflict of interest.

\section{REFERENCES}

Abiri, K., Rezaei, M., Tahanian, H., Heidari, P., And Khadivi, A. (2020). Morphological and pomological variability of a grape (Vitis vinifera L.) germplasm collection. Scientia Horticulturae, 266, 109285. doi: 10.1016/j.scienta.2020.109285.
Ali, Q., Erkan, M., And Dogan, A. (2018). Comparison of quality attributes of fig fruit ('Bursa Siyahi') harvested at two different maturity stages. Acta Horticulturae, 1275, 311-316.

Ansari, M. H., Hashemabadi, D., Mahdavi, M., and Kaviani, B. (2018). The role of Pseudomonas strains and arbuscular mycorrhiza fungi as organic phosphate-solubilizing in the yield and quality improvement of strawberry (Fragaria $\times$ ananassa Duch., cv. Selva) fruit. Acta Scientiarum Polonorum, Hortorum Cultus, 17(4), 93-107.

Arena, M. E., And Curvetto, N. (2008). Berberis buxifolia fruiting: Kinetic growth behavior and evolution of chemical properties during the fruiting period and different growing seasons. Scientia Horticulturae, 118(2), 120-127.

Centeno, D. C., Osorio, S., Nunes-Nesi, A., Bertolo, A. L., Carneiro, R. T., Araújo, W. L., Steinhauser, M.-C., Michalska, J., Rohrmann, J., Geigenberger, P., Oliver, S. N., Stitt, M., Carrari, F., Rose, J. K. C., And Fernie, A. R. (2011). Malate plays a crucial role in starch metabolism, ripening, and soluble solid content of tomato fruit and affects postharvest softening. The Plant Cell, 23(1), 162-184.

Chang, Y. L., Lin, J. T., Lin, H. L., LiaO, P. L., Wu, P. J., And YAng, D. J. (2019). Phenolic compositions and antioxidant properties of leaves of eight persimmon varieties harvested in different periods. Food Chemistry, 289, 74-83.

Colak, A. M., Okatan, V., Polat, M., and Guçlu, S. F. (2019). Different harvest times affect market quality of Lycium barbarum L. berries. Turkish Journal of Agriculture and Forestry, 43(3), 326-333.

Crisosto, C. H., AND CRisosto, G. M. (2005). Relationship between ripe soluble solids concentration (RSSC) and consumer acceptance of high and low acid melting flesh peach and nectarine (Prunus persica (L.) Batsch) cultivars. Postharvest Biology and Technology, 38(3), 239-246.

DAI, J., AND Mumper, R. J. (2010). Plant phenolics: Extraction, analysis and their antioxidant and anticancer properties. Molecules, 15(10), 7313-7352.

Demir, G., And Aktas, N. (2018). A research on functional food knowledge, preference and consumption of university students. Üniversite öğrencilerinin fonksiyonel besin bilgi, tercih ve tüketimleri üzerine bir araştırma. Journal of Human Sciences, 15(4), 2387-2397.

Donno, D., Beccaro, G. L., Mellano, M.G., Cerutti A. K., And Bounous, G. (2015). Goji berry fruit (Lycium spp.): Antioxidant compound fingerprint and bioactivity evaluation. Journal of Functional Foods, 18, 1070-1085.

Ebel, R. C., Proebsting, E. L., and Patterson, M. E. (1993). Regulated deficit irrigation may alter apple maturity, quality, and storage life. HortScience, 28(2), 141-143.

Erkan, M., And Pekmezci, M. (2004). Harvest date influences superficial scald development in Granny 
Smith apples during long term storage. Turkish Journal of Agriculture and Forestry, 28(6), 397-403.

Eskimez, I., Polat, M., Korkmaz, N., and Mertoglu, K. (2019). Investigation of some blackberry cultivars in terms of phenological, yield and fruit characteristics. International Journal of Agriculture Forestry and Life Sciences, 3(2), 233-238.

Galindo, A., Noguera-Artiaga, L., Cruz, Z. N., Burló, F., Hernández, F., Torrecillas, A., and Carbonell-Barrachina, Á. A. (2015). Sensory and physico-chemical quality attributes of jujube fruits as affected by crop load. LWT-Food Science and Technology, 63(2), 899-905.

Garcia-Gomez, B. E., Salazar, J. A., Dondini, L., Martinez-Gomez, P., And Ruiz, D. (2019a). Identification of QTLs linked to fruit quality traits in apricot (Prunus armeniaca L.) and biological validation through gene expression analysis using qPCR. Molecular Breeding, 39(2), 28, doi: 10.1007/ s11032-018-0926-7.

Garcia-Gomez, B., González-Alvarez, H., MartinezMora, C., Cenis, L. J., Pérez-Hernández, C. D. M., Martinez-Zubiaur, Y., and Martinez-Gomez, P. (2019b). The molecular characterization of an extended mulberry germplasm by SSR markers. Genetika, 51(2), 389-403.

Giusti, M. M., And Wrolstad, R. E. (2001). Characterization and measurement of anthocyanins by UV-visible spectroscopy. Current Protocols in Food Analytical Chemistry, (1), F1-2.

Hashemi, S., And Khadivi, A. (2020). Morphological and pomological characteristics of white mulberry (Morus alba L.) accessions. Scientia Horticulturae, 259, 108827, doi: 10.1016/j.scienta.2019.108827.

He, J., Yin, T., Chen, Y., Cai, L., Tai, Z., Li, Z., Liu C. H., WAng, Y., And Ding, Z. (2015). Phenolic compounds and antioxidant activities of edible flowers of Pyrus pashia. Journal of Functional Foods, 17, 371-379.

I Forcada, C. F., Gradziel, T. M., Gogorcena, Y., And Moreno, M. Á. (2014). Phenotypic diversity among local Spanish and foreign peach and nectarine [Prunus persica (L.) Batsch] accessions. Euphytica, 197(2), 261-277.

Iezzoni, A. F., And Pritt, M. P. (1991) Applications of principal com-ponent analysis to horticultural research. HortScience, 26, 334-338.

Karacali, I. (2012). Bahçe Ürünlerinin Muhafazası ve Pazarlanması. Hasat Öncesi Dönemde Gelişmeyi Etkileyen Faktörler. Ege Üniv. Yay. No: 494. Bornova, İzmir, Turkey.

Lachowicz, S., Seliga, Ł., And Pluta, S. (2020). Distribution of phytochemicals and antioxidative potency in fruit peel, flesh, and seeds of Saskatoon berry. Food Chemistry, 305, 125430, doi: 10.1016/j. foodchem.2019.125430.

Levin, R. A., And Miller, J. S. (2005). Relationships within tribe Lycieae (Solanaceae): paraphyly of Lycium and multiple origins of gender dimorphism. American Journal of Botany, 92(12), 2044-2053.
Liverani, A., Gionvannini, D., And Brandi, F. (2002). Increasing fruit quality of peaches and nectarines: The main goals of ISF-FO (Italy). Acta Horticulturae, 592, 507-514.

Lo Bianco, R., Farina, V., Indelicato, S. G., Filizzola, F., AND Agozzino, P. (2010). Fruit physical, chemical and aromatic attributes of early, intermediate and late apricot cultivars. Journal of the Science of Food and Agriculture, 90(6), 1008-1019.

Mertoglu, K., and Evrenosoglu, Y. (2019). Bazı elma ve armut çeşitlerinde fitokimyasal özelliklerin belirlenmesi. Ziraat Fakültesi Dergisi, 14(1), 11-20.

Mertoglu, K., Evrenosoglu, Y., and Polat, M. (2019a). Combined effects of ethephon and mepiquat chloride on late blooming, fruit set, and phytochemical characteristics of Black Diamond plum. Turkish Journal of Agriculture and Forestry, 43(6), 544-553.

Mertoglu, K., Gulbandilar, A., And Bulduk, İ. (2020). Growing conditions effect on fruit phytochemical composition and anti-microbial activity of plum (cv. Black Diamond). International Journal of Agriculture Forestry and Life Sciences, 4(1), 56-61.

Mertoglu, K., Polat, M., and Evrenosoglu, Y. (2019b). Erkenci armut çeşit adayı bazı $F_{1}$ melezlerin morfolojik ve ticari değerler yönünden değerlendirilmesi. Ziraat Fakültesi Dergisi, 14(2), 276-285.

Mphahlele, R. R., Stander, M. A., Fawole, O. A., And OpARA, U. L. (2014). Effect of fruit maturity and growing location on the postharvest contents of flavonoids, phenolic acids, vitamin $\mathrm{C}$ and antioxidant activity of pomegranate juice (cv. Wonderful), Scientia Horticulturae, 179, 36-45.

OKATAN, V. (2020). Antioxidant properties and phenolic profile of the most widely appreciated cultivated berry species: A comparative study. Folia Horticulturae, 32(1), 79-85.

Okatan, V., And Colak, A. M. (2019). Chemical and phytochemicals content of barberry (Berberis vulgaris L.) fruit genotypes from sivasli district of usak province of Western Turkey. Pakistan Journal of Botany, 51(1), 165-170.

Ozga, J. A., And Reinecke, D. M. (2003). Hormonal interactions in fruit development. Journal of Plant Growth Regulation, 22(1), 73-81.

Pham, T., Lecomte, S., Efstathiou T., Ferriere F. And Pakdel, F. (2019). An update on the effects of glyceollins on human health: Possible anticancer effects and underlying mechanisms. Nutrients, 11(1), 79 .

Potterat, O. (2010). Goji (Lycium barbarum and $L$. chinense): Phytochemistry, pharmacology and safety in the perspective of traditional uses and recent popularity. Planta Medica, 76(01), 7-19.

Radunic, M., Špika, M. J., Ban, S. G., Gadže, J., DiazPérez, J. C., And Maclean, D. (2015). Physical and chemical properties of pomegranate fruit accessions from Croatia. Food Chemistry, 177, 53-60. 
Rakonjac, V., Akšić, M. F., Nikolić D., Milatović, D., AND Čolić, S. (2010). Morphological characterization of 'Oblačinska' sour cherry by multivariate analysis. Scientia Horticulturae, 125(4), 679-684.

Reig, G., Mestre, L., Betrán, J. A., Pinochet, J., And Moreno, M. Á. (2016). Agronomic and physicochemical fruit properties of 'Big Top'nectarine budded on peach and plum based rootstocks in Mediterranean conditions. Scientia Horticulturae, 210, 85-92.

Sage, R. F., And Kubien, D. S. (2007). The temperature response of $\mathrm{C} 3$ and $\mathrm{C} 4$ photosynthesis. Plant, Cell and Environment, 30(9), 1086-1106.

Saridas, M. A., Kapur, B., Çeliktopuz, E., And Kargi, S. P. (2017). Irrigation regimes and bio-stimulant application effects on fruit quality features at 'Rubygem' strawberry variety. Turkish Journal of Agriculture - Food Science and Technology, 5(10), 1221-1227.

Selcuk, N., and Erkan, M. (2014). Changes in antioxidant activity and postharvest quality of sweet pomegranates cv. Hicrannar under modified atmosphere packaging. Postharvest Biology and Technology, 92, 29-36.

Selcuk, N., ANd Erkan, M. (2016). Impact of passive modified atmosphere packaging on physicochemical properties, bioactive compounds, and quality attributes of sweet pomegranates. Turkish Journal of Agriculture and Forestry, 40(4), 475-488.

Szot, I., Lipa, T., And Sosnowska, B. (2019). Evaluation of yield and fruit quality of several ecotypes of cornelian cherry (Cornus mas L.) in Polish conditions. Acta Scientiarum Polonorum, Hortorum Cultus, 18(6), 141-150.

TANG, Y., AND TsaO, R. (2017). Phytochemicals in quinoa and amaranth grains and their antioxidant, anti inflammatory, and potential health beneficial effects: A review. Molecular Nutrition and Food Research, 61(7). doi: 10.1002/mnfr.201600767.
Tomas-Barberan, F. A., And Espin, J. C. (2001). Phenolic compounds and related enzymes as determinants of quality in fruits and vegetables. Journal of the Science of Food and Agriculture, 81(9), 853-876.

Usanmaz, S., Ozturkler, F., Helvaci, M., Turgut, A., Kahramanoglu, I., And AșKin, M. A. (2018). Effects of periods and altitudes on the phenolic compounds and oil contents of olives, cv. Ayvalik. International Journal of Agriculture Forestry and Life Sciences, 2(2), 32-39.

Verdaguer, D., Jansen, M. A., Llorens, L., Morales, L. O., AND Neugart, S. (2017). UV-A radiation effects on higher plants: Exploring the known unknown. Plant Science, 255, 72-81.

Vieira, F. G. K., Borges, G. D. S. C., Copetti, C., Amboni, R. D. D. M. C., Denardi, F., and Fett, R. (2009). Physico-chemical and antioxidant properties of six apple cultivars (Malus domestica Borkh) grown in southern Brazil. Scientia Horticulturae, 122(3), 421-425.

Villalobos-Gonzalez, L., Peña-Neira, A., IbáÑez, F., And Pastenes, C. (2016). Long-term effects of abscisic acid (ABA) on the grape berry phenylpropanoid pathway: Gene expression and metabolite content. Plant Physiology and Biochemistry, 105, 213-223.

ZAR, J. H. (2013). Biostatistical analysis: Pearson new international edition. Harlow, UK: Pearson Higher Ed.

Zheng, L., Zhou, X., MA, Y., And Guo, M. (2019). Genome-wide identification and characterization of TCP family genes associated with flower and fruit development in Fragaria vesca. Pakistan Journal of Botany, 51(2), 513-519.

Zorenc, Z., Veberic, R., Stampar, F., Koron, D., and MikulicpetKovsek, M. (2016). Changes in berry quality of northern highbush blueberry (Vaccinium corymbosum L.) during the harvest season. Turkish Journal of Agriculture and Forestry, 40(6), 855-864.

Received July 18, 2020; accepted September 4, 2020 